\title{
Silicate fertilizer and irrigation depth in corn production ${ }^{1}$
}

\author{
Edvaldo Eloy Dantas Júnior ${ }^{2}$, Lucia Helena Garófala Chaves ${ }^{3}$, \\ Fernando Antônio Melo da Costa ${ }^{4}$ Hans Raj Gheyi ${ }^{5}$
}

\begin{abstract}
Calcium-magnesium silicates improve the soil physicochemical properties and provide benefits to plant nutrition, since they are sources of silica, calcium and magnesium. The objective of this study was to evaluate the grain yield of irrigated corn fertilized with calcium-magnesium silicate. The experiment was carried out in a greenhouse in Campina Grande - PB, Brazil, using plastic pots containing $80 \mathrm{~kg}$ of soil. The treatments consisted of the combination of four irrigation depths, related to water replacement of 50, 75, 100 and 125\% of the crop evapotranspiration, with fertilizer levels of $0,82,164$ and $246 \mathrm{~g}$ of calcium-magnesium silicate, with three replications. The experimental design was in randomized blocks, with the irrigation depths distributed in bands while the silicon levels constituted the subplots. Corn yield was influenced by calcium-magnesium silicate and by irrigation depth, obtaining the greatest grain yield with the dose of $164 \mathrm{~g} \mathrm{pot}^{-1}$ irrigated at the highest water level. The water-use efficiency of in corn production tended to decrease when the irrigation depth was increased. The best water-use efficiency was observed when the irrigation level was between 87 and $174 \mathrm{~mm}$, and the dose of silicate was $164 \mathrm{~g} \mathrm{pot}^{-1}$.
\end{abstract}

Key words: silicon, irrigated corn, grain production.

\section{RESUMO}

\section{Adubação silicatada e lâminas de irrigação na produção do milho}

Os silicatos de cálcio e magnésio, quando aplicados aos solos, têm efeito sobre suas propriedades físico-químicas e sobre a nutrição de plantas, uma vez que são fontes de silício, cálcio e magnésio. O objetivo deste trabalho foi avaliar a produção de grãos de milho, irrigado e adubado com silicato de cálcio e magnésio. O experimento foi conduzido em casa de vegetação, no município de Campina Grande- PB, utilizando-se vasos plásticos com $80 \mathrm{~kg}$ de solo. Os tratamentos resultaram da combinação de quatro lâminas de irrigação, referentes a reposições de água, correspondentes a 50, 75,100 e $125 \%$ da evapotranspiração da cultura, com níveis de adubação de 0, 82, 164 e 246 g de silicato de cálcio e magnésio, com três repetições. O delineamento experimental foi em blocos ao acaso, sendo as lâminas de água distribuídas em faixas e as doses de silício compondo as subparcelas. A produção do milho foi significativamente influenciada pelas dosagens de silicato de cálcio e magnésio e pelas lâminas de água, obtendo-se a maior produção de grãos com a dosagem de $164 \mathrm{~g} \mathrm{vaso}^{-1}$ e maior lâmina de irrigação. A eficiência de uso da água na produção de grãos de milho tendeu a diminuir, sempre que as lâminas de irrigação aumentaram. A melhor eficiência de uso da água ocorreu com a utilização de lâminas entre 87 e 174 mm e da dose de silicato de 164 g vaso $^{-1}$.

Palavras-chave: silício, milho irrigado, produção de grãos.

\footnotetext{
Received: 30/12/2011; Accepted: 13/05/2013.

'Part of the Master's thesis of the first author, presented to the Post-graduation Program in Agricultural Engineering at Universidade Federal de Campina Grande. ${ }^{2}$ Agricultural Engineer, Master of Science. Departamento de Engenharia Agrícola, Universidade Federal de Campina Grande, Avenida Aprígio Veloso, 882, 58429-140, Campina Grande, Paraíba, Brazil. edvaldoeloyjr@gmail.com

${ }^{3}$ Agronomist Engineer, Doctor of Science. Departamento de Engenharia Agrícola, Universidade Federal de Campina Grande, Avenida Aprígio Veloso, 882, 58429-140, Campina Grande, Paraíba, Brazil. lhgarofalo@ hotmail.com (corresponding author).

${ }^{4}$ Undergraduate student in Agricultural Engineering. Universidade Federal de Campina Grande, Avenida Aprígio Veloso, 882, 58429-140, Campina Grande, Paraíba, Brazil. nando_ufcg@hotmail.com

${ }^{5}$ Agronomist Engineer, Doctor of Science. Núcleo de Engenharia de Água e Solo, Universidade Federal do Recôncavo da Bahia, Campus Universitário Cruz das Almas, Caixa Postal 10078, 44380-000, Cruz das Almas, Bahia, Brazil. hans@pq.cnpq.br
} 


\section{INTRODUCTION}

Metallurgy slags, when applied especially on low fertility sandy soils, improve its physicochemical properties and provide benefits to plant nutrition, since they are sources of silica, calcium and magnesium (Korndörfer et al., 2004). Most of the studies involving metallurgy slags have shown its effect on soil acidity correction and as soil fertilizer, since it enhances calcium and magnesium levels and, possibly, increases the phosphorus availability (Prado \& Fernandes, 2000).

Calcium plays an important role as an essential part of the plant cell, straightening the cell wall structure. Similarly, positive effects of silicon on metabolic, physiologic and structural activities have been observed in several plants, either silicon accumulating or not (Liang et al., 2007). According to Ma et al. (2001), this plant classification is related to the molar ratio $\mathrm{Si}: \mathrm{Ca}$ in plant tissues, i.e., accumulating and non-accumulating plants present the aforementioned ratio of greater than one and less than 0.5 , respectively. However, according to $\mathrm{Ma}$ et al. (2003), silicon is accumulated in high levels on tissues of almost every plant species; in case of phytosanitary issues, silicon can provide an increase on plant resistance to insects and diseases (Epstein, 2001; Belanger et al., 2003; Richmond \& Sussman, 2003).

Responsible for activating a great variety of plant enzymes and being an important component of the chlorophyll, magnesium plays vital roles in plant production, such as silicon, which, according to Epstein (2001) and Nojosa et al. (2006), is the responsible for the increase of chlorophyll levels and for the leaf metabolism.

Owino-Gerroh \& Gascho (2004) and Mali \& Aery (2009) observed a reduction of plant lodging and a gain of productivity in corn and macassar beans by using increasing doses of silicon.

In grain crops such as corn, rice and sorghum, silica is deposited in the form of silica bodies, mainly on epidermal cells, which are siliceous and bulliform, and on stomata and leaf trichomas (Currie \& Perry, 2007). Silica accumulation in the transpiration organs causes the formation of a double layer of cuticular silica, reducing the water loss by transpiration, which increases the water-use efficiency by the plant and enhances the resistance to biotic and abiotic stresses, such as the ones caused by chewing insects (Nwugo \& Huerta, 2008). According to Kaya et al. (2006), the addiction of silicon increased the tolerance to water stress in corn seedlings, maintaining the membrane permeability.

Therefore, the need of further research on the effects of metallurgy slag in agricultural crops in evident. Thus, the objective of this study was to evaluate the effects of calcium-magnesium silicate and water levels on corn grown under greenhouse conditions.

\section{MATERIAL AND METHODS}

The experiment was carried out in a greenhouse of the Department of Agricultural Engineering at Universidade Federal de Campina Grande, Campina Grande, Paraíba State, Brazil, in 2009.

For the experiment, plastic pots with $100 \mathrm{~L}$ capacity drilled in the base for drainage, were used. The pots were filled with $80 \mathrm{Kg}$ of soil (Entisol Eutrophic) collected in the topsoil, presenting the main characteristics: sand $=841.5 \mathrm{~g} \mathrm{~kg}^{-1}$; silt $=$ $87.5 \mathrm{~g} \mathrm{~kg}^{-1}$; clay $=71.0 \mathrm{~g} \mathrm{~kg}^{-1} ; \mathrm{pH}\left(\mathrm{H}_{2} \mathrm{O}\right)=6.6 ; \mathrm{Ca}=2.55 \mathrm{cmol}_{\mathrm{c}}$ $\mathrm{kg}^{-1} ; \mathrm{Mg}=2.23 \mathrm{cmol}_{\mathrm{c}} \mathrm{kg}^{-1} ; \mathrm{Na}=0.06 \mathrm{cmol}_{\mathrm{c}} \mathrm{kg}^{-1}, \mathrm{~K}=0.28 \mathrm{cmol}_{\mathrm{c}}$ $\mathrm{kg}^{-1} ; \mathrm{H}=0.79 \mathrm{cmol}_{\mathrm{c}} \mathrm{kg}^{-1} ; \mathrm{Al}=0.00 \mathrm{cmol}_{\mathrm{c}} \mathrm{kg}^{-1}$, organic matter $=8.4 \mathrm{~g} \mathrm{~kg}^{-1}$ and $\mathrm{P}=28.5 \mathrm{mg} \mathrm{kg}^{-1}$.

The experimental design was a randomized block, with three replicates. The water levels were distributed in bands while the subplots were constituted by the doses of calcium-magnesium silicate. The treatments consisted of the combination of four water levels regarding to the water replacement $(50,75,100$ and $125 \%$ of the crop evapotranspiration), with four doses of calciummagnesium silicate $(0,82,164$ and $246 \mathrm{~g})$ of the soil in each pot with one plant, consisting one experimental unit. The calcium-magnesium silicate came from the slag of stainless steel production (Acesita), treated by Recmix do Brasil, containing: $25.0 \%$ of calcium; $6.0 \%$ of magnesium and $10.5 \%$ of silicon.

The soil was mixed with the silicate, according to the treatments aforementioned. Initially, the mixture was incubated and kept at field capacity for 30 days, so the silicate could react with the soil. After that, the mixture was fertilized with nitrogen, phosphorus and potassium, according to Novais et al. (1991), using $100 \mathrm{mg}$ of $\mathrm{N} ; 300$ $\mathrm{mg}$ of $\mathrm{P}_{2} \mathrm{O}_{5}$ and $150 \mathrm{mg}$ of $\mathrm{K}_{2} \mathrm{O}$ per kilogram of soil, using as source: urea ( $46 \%$ of $\mathrm{N})$, triple superphosphate ( $46 \%$ of $\left.\mathrm{P}_{2} \mathrm{O}_{5}\right)$ and potassium chloride $\left(60 \%\right.$ of $\left.\mathrm{K}_{2} \mathrm{O}\right)$, respectively. All the phosphorus was added in one application while the nitrogen and potassium doses were added in two applications, the first one during the seeding and the second one 15 after the germination.

After fertilization, five seeds of corn BRS Caatingueiro were sown per pot, and two plants per pot were grown up to the end of the experiment.

For water supply, the pressurized irrigation method was used, adopting the drip irrigation system. The water used for irrigation came from the urban supply.

The amount of water applied in irrigation was quantified based on the Class A pan installed in the greenhouse. The reference crop evapotranspiration $\left(\mathrm{ET}_{0}\right)$ inside the greenhouse was calculated by multiplying $\mathrm{Kp}$ (equal to 1.0) by the evaporation (EV) daily measured in the Class A pan, according to the equation $\mathrm{ET}_{0}=\mathrm{Kp} \times \mathrm{EV}$. To calculate the crop 
evapotranspiration ( $\left.\mathrm{ET}_{\mathrm{c}}\right)$, the crop coefficient $\left(\mathrm{K}_{\mathrm{c}}\right)$ was multiplied by the reference crop evapotranspiration, according to the equation $\mathrm{ET}_{\mathrm{c}}=\mathrm{K}_{\mathrm{c}} \times \mathrm{ET}_{0}$.

At first, $\mathrm{K}_{\mathrm{c}}$ adopted was equal to 0.7 during the phenological stage, corresponding to the emission of the second to the fourth completely expanded leaf. The $\mathrm{K}_{c}$ adopted varied according to the corn development, using 0.87 until the emission of the eighth leaf, 1.04 from the eighth to the tenth leaf and 1.20 from the tenth to the twelfth completely expanded leaf. This last value $\left(\mathrm{K}_{\mathrm{c}}=\right.$ 1.20) was adopted during tassel emission, flowering (ear emission), pollination and kernel milk stage. At the kernel dent stage, before the physiological maturity, when the kernels presented a black layer in the ear intersection, the $\mathrm{K}_{\mathrm{c}}$ adopted was 0.35 . The leaf was considered completely expanded when the joint line leaf-sheath could be easily seen.

The water levels, in volume (assessed in liters), were calculated by multiplying the $\mathrm{ET}_{\mathrm{c}}$ at each development stage of the crop by $0.5,0.75,1.0$ and 1.25 , obtaining the irrigation depths $\mathrm{I}_{1}, \mathrm{I}_{2}, \mathrm{I}_{3}$ and $\mathrm{I}_{4}\left(\mathrm{~mm} \mathrm{day}^{-1}\right.$ or L m $\left.\mathrm{day}^{-1}\right)$, corresponding to the replacement of 50, 75, 100 and $125 \%$ of the crop evapotranspiration. Afterwards, the irrigation depths $I_{1}, I_{2}, I_{3}$ and $I_{4}$ were multiplied by the surface area of the pot $\left(\mathrm{S}_{\mathrm{pot}}=0.13 \mathrm{~m}^{2}\right)$, obtaining the volume required to supply the daily water levels.

The harvest was manually performed, when the grains were dry. The production was evaluated by weighing the kernels (obtaining the kernel weight per plant, in grams), after drying in a forced-air convection oven at $60^{\circ} \mathrm{C}$, until approximately $13 \%$ of moisture.

The water-use efficiency (WUE) was calculated by the ratio between corn yield (weight of dry kernels) and the water consumption during the production stage, when different irrigation depths were used (totalizing 86 days).

The effects of irrigation depths and calciummagnesium silicate doses were evaluated through polynomial regression using the program SISVAR version 5.1. The curves with the greatest $\mathrm{R}^{2}$, obtained by regression analyses through the F test, followed the quadratic models:

$\mathrm{G}=\mathrm{aI} \mathrm{I}^{2}+\mathrm{bI}+\mathrm{c}$

$\mathrm{G}=\mathrm{aD}_{\text {Silicate }}{ }^{2}+\mathrm{bD}_{\text {Silicate }}+\mathrm{c}$

$\mathrm{WUE}=\mathrm{a} \mathrm{I}^{2}+\mathrm{bI}+\mathrm{c}$

$\mathrm{WUE}=\mathrm{aD}_{\text {Silicate }}{ }^{2}+\mathrm{bD}_{\text {Silicate }}+\mathrm{c}$

Where $\mathrm{G}$ is the grain yield, WUE is the water-use efficiency, $\mathrm{I}$ is the irrigation depth and $\mathrm{D}_{\text {silicate }}$ is the dose of calcium-magnesium silicate; $a, b$ and $c$ are the regression coefficients.

\section{RESULTS AND DISCUSSION}

Corn yield and the water-use efficiency (WUE) were influenced by irrigation depths and calcium-magnesium silicate doses and by their interaction at $1 \%$ probability (Table 1). These results disagree with those obtained by Prado \& Korndörfer (2003), which observed no effect of silicate fertilization in corn. Similarly, Orioli Júnior et al. (2008) observed that silicium fertilization $(0,50,100,150$, 200 e $250 \mathrm{~kg} \mathrm{ha}^{-1}$ of Si) did not influence wheat yield.

Medeiros et al. (2009) observed no difference in wateruse efficiency in sugar cane fertilized with silicate. According to Melo et al. (2003), silicon fertilization (0, 242, 484, $968 \mathrm{e}$ $1452 \mathrm{~kg} \mathrm{ha}^{-1}$ ) under 2 water regime in soil (60 and $80 \%$ of field capacity) in 2 Brachiaria species (Brachiaria decumbens Stapf and Brachiaria brizantha Hochst.), did not improve the drought tolerance nor influenced the dry mass production in both species. Although, the addition of fertilizer rich in calcium-magnesium silicates increased drought tolerance, keeping the membrane permeability, in corn seedlings (Kaya et al., 2006), indicating that those plants used the irrigation water efficiently (Table 1).

The polynomial regression analysis indicated that the average data of production and WUE, regarding to the variation in irrigation depths, were adjusted to the quadratic model significant at $1 \%$ probability with high determination coefficients, presenting variations in each dose of calcium-magnesium silicate (Table 2).

The inflection points of production and WUE curves (Figure 1), estimated by the statistical models shown in Table 2, for calcium-magnesium silicate fertilization at the doses 0,82 and $164 \mathrm{~g} \mathrm{plant}^{-1}$ and for irrigation depths, presented the lowest values of 45,53 and $47 \mathrm{~g} \mathrm{plant}^{-1}$, at the irrigation depths of 128, 67 and $26 \mathrm{~mm}$, respectively, for grain yield. For WUE, the respective minimum points were $0.33,0.49$ and $0.58 \mathrm{~g} \mathrm{~mm}^{-1}$ using the irrigation depth of 161,156 and $150 \mathrm{~mm}$, respectively.

From these minimum points, it was observed an increase tendency of grain yield and WUE, with the increment of the irrigation depth for each dose of silicate used. For the silicate dose of $246 \mathrm{~g}$ per pot, an increase was observed until the maximum grain yield of $124 \mathrm{~g}$ plant $^{-1}$, using irrigation depth of $220 \mathrm{~mm}$ and WUE of $0.58 \mathrm{~g} \mathrm{~mm}^{-1}$, with irrigation depth of $162 \mathrm{~mm}$. Onwards from these values a decrease was observed in production as well as in WUE (Figure 1).

According to Herrero \& Johnson (1981), the effects of drought stress in corn physiology are evident in the development of the male part of the flower and on the pollen production, causing a reduction of kernels per ear.

Given the aforementioned, the inferior grain yield per plant observed in the treatments with low irrigation depths can be explained by the drought stress which those plants were submitted. 
Analyzing the grain yield and the WUE, for each irrigation depth applied and with the variation of calcium-magnesium doses, an adjustment of $1 \%$ probability was observed, with high determination coefficients for polynomial regression, as shown on Table 3.
The graphs (Figure 2) of the regression models (Table 3) represent the production and WUE behavior with acceptable accuracy, as their models were significant at $1 \%$ probability (Figure 2 ).

The lower production observed in plants grown in the absence of calcium-magnesium silicate may be related to

Table 1. Analysis of variance for corn production and water-use efficiency

\begin{tabular}{|c|c|c|c|c|c|c|c|}
\hline \multirow{2}{*}{ Source of variation } & \multirow{2}{*}{ DF } & \multicolumn{3}{|c|}{ Corn Production } & \multicolumn{3}{|c|}{ Water use efficiency } \\
\hline & & MS & Fc & Pr $>$ Fc & AS & Fc & Prob F \\
\hline Block & 2 & 10.46 & 0.93 & $0.4446^{\mathrm{ns}}$ & 0.00083 & 1.48 & $0.2989^{\mathrm{ns}}$ \\
\hline Irrigation Depth (I) & 3 & 12404.9 & 1102.92 & $0.0000 * *$ & 0.04593 & 82.16 & $0.0000 * *$ \\
\hline Error 1 & 6 & 11.25 & - & - & 0.00055 & - & - \\
\hline Silicate dose (Si) & 3 & 1100.13 & 42.21 & $0.0002 * *$ & 0.03995 & 49.73 & $0.0001 * *$ \\
\hline Error 2 & 6 & 26.06 & - & - & 0.0008 & - & - \\
\hline Interaction (I X Si) & 9 & 549.4 & 22.89 & $0.0000 * *$ & 0.02349 & 25.52 & $0.0000 * *$ \\
\hline Error 3 & 18 & 24 & - & - & 0.00092 & & - \\
\hline Total adjusted & 47 & & & & & & \\
\hline Variation coefficients (CV) & $4.00 \%$ & & $4.27 \%$ & & & & \\
\hline
\end{tabular}

${ }^{\text {ns }}$ Not Significant; ${ }^{* *}$ Significant at $1 \%$ probability; DF - Degree of freedom; MS - Mean Square; Fc- F calculated

Table 2. Regression models and mean squares for corn production and water-use efficiency, regarding to irrigation depths inside each silicate dose

\begin{tabular}{|c|c|c|c|c|c|}
\hline \multirow{2}{*}{$\begin{array}{l}\text { Silicate dose } \\
\text { g pot }^{-1}\end{array}$} & \multicolumn{5}{|c|}{ Production $(\mathrm{P}), \mathrm{g}_{\text {plant }}{ }^{-1}$} \\
\hline & Regression model & $\mathbf{R}^{2}$ & MS & Fc & Prob F \\
\hline 0 & $\mathrm{P}=0.0086^{* *} \mathrm{I}^{2}-2.202 * * \mathrm{I}+186.16^{* *}$ & 0.928 & 3087.07 & 128.62 & $0.0000 * *$ \\
\hline 82 & $\mathrm{P}=0.0035^{* *} \mathrm{I}^{2}-0.472 * \mathrm{I}+68.80^{* *}$ & 0.929 & 3884.57 & 161.85 & $0.0000 * *$ \\
\hline 164 & $\mathrm{P}=0.0026 * * \mathrm{I}^{2}-0.137^{\mathrm{ns}} \mathrm{I}+49.29 * *$ & 0.969 & 4253.16 & 177.2 & $0.0000 * *$ \\
\hline 246 & $\mathrm{P}=-0.0019 * \mathrm{I}^{2}+1.112 * * \mathrm{I}-39.20 *$ & 0.999 & 2828.31 & 117.84 & $0.0000 * *$ \\
\hline \multirow{2}{*}{ Silicate dose } & \multicolumn{5}{|c|}{ Water use efficiency (WUE), $\mathrm{g} \mathrm{mm}^{-1}$} \\
\hline & Regression model & $\mathbf{R}^{2}$ & AS & Fc & Prob F \\
\hline 0 & WUE $=0.00006 * * \mathrm{I}^{2}-0.019 * * \mathrm{I}+1.89 * *$ & 0.955 & 0.0659 & 79.88 & $0.0000 * *$ \\
\hline 82 & WUE $=0.00003 * * I^{2}-0.0094 * * I+1.22 * *$ & 0.442 & 0.0319 & 38.76 & $0.0000 * *$ \\
\hline 164 & WUE $=0.000022^{* *} \mathrm{I}^{2}-0.0066 * * \mathrm{I}+1.07 * *$ & 0.455 & 0.0155 & 18.78 & $0.0000 * *$ \\
\hline 246 & WUE $=-0.000013 * * \mathrm{I}^{2}+0.0042 * * \mathrm{I}+0.24 * *$ & 0.999 & 0.0031 & 3.72 & $0.0215 *$ \\
\hline
\end{tabular}

${ }^{*}$ Significant at $1 \%$ probability; ${ }^{*}$ Significant at $5 \%$ probability; I - Irrigation depth; $\mathrm{R}^{2}$ - determination coefficients; MS - Mean squares; Fc - F calculated; Prob F - model significance

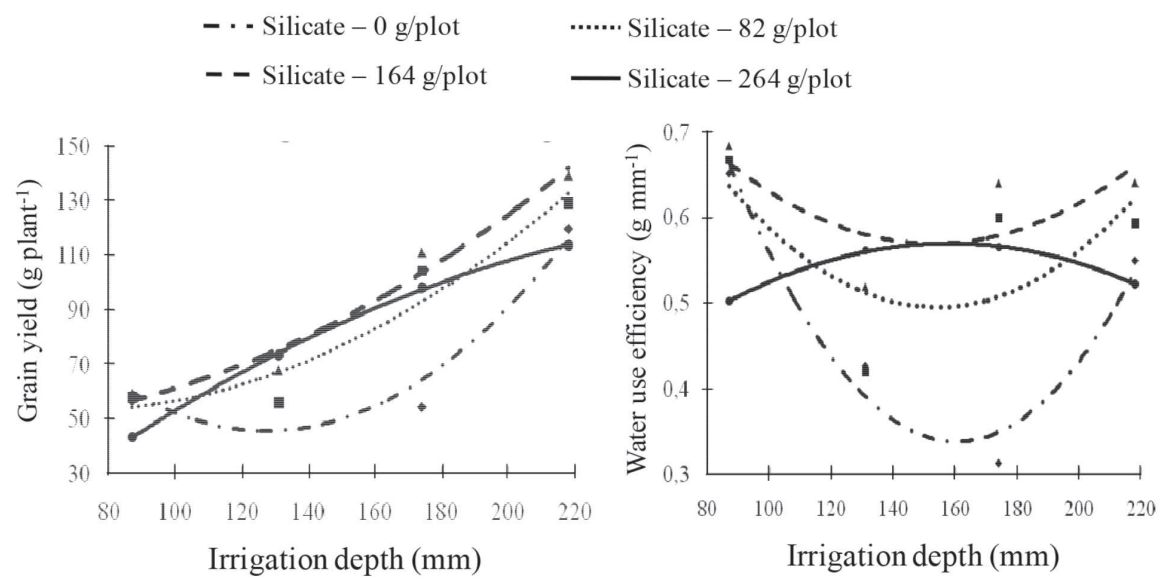

Figure 1. Variation of grain yield and water-use efficiency, according to the irrigation depth for each dose of calcium-magnesium silicate.

Rev. Ceres, Viçosa, v. 60, n.4, p. 563-568, jul/ago, 2013 
the lower levels of calcium and magnesium in the soil, due to the lack of silicate containing those elements.

Although, when $82 \mathrm{~g}$ of calcium-magnesium silicate was used, the production increased $21.22 \%$ compared to the control ( $0 \mathrm{~g}$ of calcium-magnesium silicate). The treatments fertilized with $164 \mathrm{~g}$ of silicate had greater production, with an increase of $69.19 \%$ compared to the control. It is worth mentioning that the increase of silicate doses from 82 to $164 \mathrm{~g}$ resulted in a production gain of $8.8 \%$, while from 164 to $246 \mathrm{~g}$, the production decreased in $12.99 \%$.

The irrigation curves of 87,174 and $218 \mathrm{~mm}$ presented the peak production of 93,110 and $121 \mathrm{~g} \mathrm{plant}^{-1}$, using silicate doses of 61,116 and $137 \mathrm{~g} \mathrm{pot}^{-1}$, respectively. From these points, the tendency was of production decrease. The irrigation depth of $131 \mathrm{~mm}$ presented the lowest production of $54 \mathrm{~g}$ plant $^{-1}$ when fertilized with 76.5 $\mathrm{g} \mathrm{pot}^{-1}$ of calcium-magnesium silicate. Nonetheless, the water-use efficiency for every irrigation depth had a maximum peak. The highest WUE values were observed at 87 and $174 \mathrm{~mm}$, according to the second-order polynomial regression curves, with 0.70 and $0.78 \mathrm{~g} \mathrm{~mm}^{-1}$, respectively, fertilized with 93 and $215 \mathrm{~g} \mathrm{pot}^{-1}$ of silicate. At the irrigation depths 131 and $218 \mathrm{~mm}$, the WUE were 0.63 and $0.62 \mathrm{~g} \mathrm{~mm}^{-1}$, fertilized with 130 and $117 \mathrm{~g} \mathrm{pot}^{-1}$ of calcium-magnesium silicate, respectively.

According to the regression models, in the absence of calcium-magnesium silicate, the greatest production average was observed at irrigation depth of $218 \mathrm{~mm}$ (125\% of ET $\mathrm{C}_{\mathrm{c}}$. . On the other hand, the production of plants fertilized with calcium-magnesium silicate increased according to the irrigation depths, and the greatest productions were observed at the two highest irrigation depths, 174 and $218 \mathrm{~mm}$, corresponding to 100 and $125 \%$ of the ET, respectively. These results showthe importance of appropriate irrigation depth in crop production.

Fertilization with calcium-magnesium silicate usually enhances the growth in several crops, including corn (Ma

Table 3. Regression models and average squares for corn production and water-use efficiency, regarding to doses of calciummagnesium silicate inside each irrigation depth

\begin{tabular}{|c|c|c|c|c|c|}
\hline \multirow{2}{*}{$\begin{array}{l}\text { Irrigation } \\
\text { depth mm }\end{array}$} & \multicolumn{5}{|c|}{ Production (P), g plant ${ }^{-1}$} \\
\hline & Regression Model & $\mathbf{R}^{2}$ & AS & Fc & Prob F \\
\hline 87 & $\mathrm{P}=-0.0006 * * \mathrm{D}_{\text {Silicate }}{ }^{2}+0.111 * \mathrm{D}_{\text {Silicate }}+55.81 * *$ & 0.906 & 160.46 & 6.68 & $0.0031 * *$ \\
\hline 131 & $\mathrm{P}=0.0002 * \mathrm{D}_{\text {Silicate }}^{2}+0.314 * \mathrm{D}_{\text {Silicate }}+54.99 * *$ & 0.929 & 232.66 & 9.69 & $0.0005 * *$ \\
\hline 174 & $\mathrm{P}=-0.0023 * * \mathrm{D}_{\text {Silicate }}{ }^{2}+0.744 * * \mathrm{D}_{\text {Silicate }}+55.62 * *$ & 0.987 & 1972.49 & 82.18 & $0.0000 * *$ \\
\hline 218 & $\mathrm{P}=-0.0013 * * \mathrm{D}_{\text {Silicate }}{ }^{2}+0.314 * * \mathrm{D}_{\text {Silicate }}+117.97 * *$ & 0.822 & 382.74 & 15.94 & $0.0000 * *$ \\
\hline \multirow{2}{*}{$\begin{array}{l}\text { Irrigation } \\
\text { depth } \mathrm{mm}\end{array}$} & \multicolumn{5}{|c|}{ Water use efficiency (WUE), $\mathrm{g} \mathrm{mm}^{-1}$} \\
\hline & Regression model & $\mathbf{R}^{2}$ & AS & Fc & Prob F \\
\hline 87 & WUE $=-0.000007 * * \mathrm{D}_{\text {Silicato }}{ }^{2}+0.0013 * * \mathrm{D}_{\text {Silicato }}+0.64 * *$ & 0.917 & 0.0217 & 26.29 & $0.0000 * *$ \\
\hline 131 & WUE $=-0.00001 * \mathrm{D}_{\text {Silicato }}{ }^{2}+0.0026^{*} \mathrm{D}_{\text {Silicato }}+0.46^{* *}$ & 0.392 & 0.0138 & 16.72 & $0.0000 * *$ \\
\hline 174 & WUE $=-0.00001 * * \mathrm{D}_{\text {Silicato }}{ }^{2}+0.0043 * * \mathrm{D}_{\text {Silicato }}+0.32 * *$ & 0.986 & 0.0667 & 80.94 & $0.0000 * *$ \\
\hline 218 & WUE $=-0.000006 * * \mathrm{D}_{\text {Silicato }}{ }^{2}+0.0014 * * \mathrm{D}_{\text {Silicato }}+0.54 * *$ & 0.822 & 0.0082 & 9.95 & $0.0001 * *$ \\
\hline
\end{tabular}

$87 \mathrm{~mm}=11.31 \mathrm{~L} \mathrm{pot}^{-1} ; 131 \mathrm{~mm}=17.03 \mathrm{~L} \mathrm{pot}^{-1} ; 174 \mathrm{~mm}=22.62 \mathrm{~L} \mathrm{pot}^{-1} ; 218 \mathrm{~mm}=28.34 \mathrm{~L} \mathrm{pot}^{-1} ; *$ Significant at $1 \%$ probability; ${ }^{*}$ Significant at $5 \%$ probability; $\mathrm{D}_{\text {Silicate }}$ - dose of calcium-magnesium silicate; $\mathrm{R}^{2}$ - determination coefficients; MS - Mean squares; Fc - F calculated; Prob F - model significance.

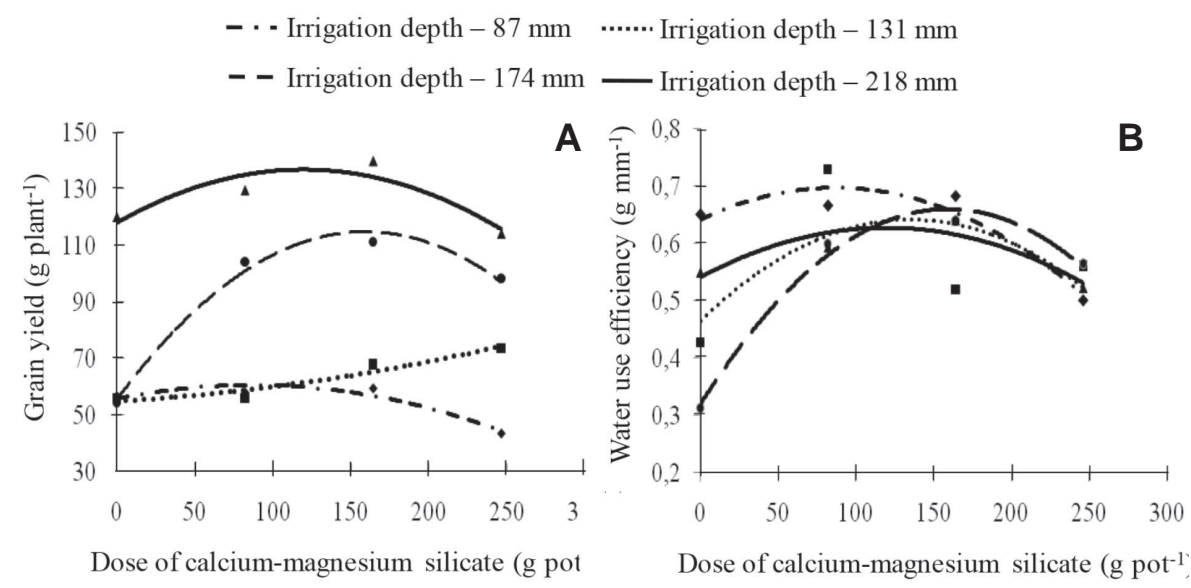

Figure 2. Variation of grain yield and water-use efficiency, according to the doses of calcium-magnesium silicate for each irrigation depth. 
et al., 2001). According to Savant et al. (1999) the greater crop production promoted by silicates is due to its effect on plant architecture, making the leaves more erect, enhancing light gathering, which increases $\mathrm{CO}_{2}$ absorption and reduces transpiration. Thus, silicate fertilization increases photosynthesis rate and provides greater water-use efficiency.

The increase of Si concentration in soil solution also alters the cation-anion balance in the plants and increases the concentration of organic acids in plants tissues, promoting the development (Owino-Gerroh \& Gascho, 2004).

\section{CONCLUSIONS}

The grain yield was influenced by irrigation depths, by calcium-magnesium silicate doses and by the interaction between those factors.

The dose of calcium-magnesium silicate that provided the greatest grain yield and water use efficiency, among all irrigation depths used, was $164 \mathrm{~g} \mathrm{pot}^{-1}$.

The irrigation depth that provided the greatest averages of grain yield, among all calcium-magnesium silicate doses, was $218 \mathrm{~mm}$, while the best water-use efficiency (among all irrigation depths) were observed at 87 and $174 \mathrm{~mm}$.

\section{ACKNOWLEDGEMENTS}

To Hascos Minerais for the donation of the silicate, and to Coordenação de Aperfeiçoamento de Pessoal de Nível Superior - CAPES, for granting a scholarship to the first author.

\section{REFERENCES}

Belanger RR, Benhamou N \& Menzies JG (2003) Cytological evidence of an active role of silicon in wheat resistance to powdery mildew (Blumeria graminis f. $\mathrm{sp}$. tritici). Phytopathology, 93:402-412.

Currie HA \& Perry CC (2007) Silica in plants: Biological, biochemical and chemical studies. Annals of Botany, 100:13831389.

Epstein E (2001) Silicon in plants: facts vs concepts. In: Datnoff LE, Snyder GH \& Korndörfer GH (Eds.) Silicon in agriculture: Studies in plant science. Amsterdam, Elsevier Science. p.1-15.

Herrero MP \& Johnson RR (1981) Drought stress and its effects on maize reproductive systems. Crop Science, 21:105-110.

Kaya C, Tuna L \& Higgs D (2006) Effects of silicon on plant growth and mineral nutrition of maize grown under water-stress conditions. Journal of Plant Nutrition, 29:1469-1480.

Korndörfer GH, Pereira HS \& Nolla A (2004) Análise de silício: Solo planta e fertilizante. $2^{\mathrm{a}}$ ed. Uberlândia, GPSi-ICIAG-UFU. 50p. (Boletim Técnico, 2).

Liang YC, Sun W, Zhu YG \& Christie P (2007) Mechanisms of silicon-mediated alleviation of abiotic stresses in higher plants: a review. Environmental Pollution, 147:422-428.
Ma JF, Higashitani A, Sato K \& Takeda K (2003) Genotypic variation in silicon concentration of barley grain. Plant and Soil, 249:383-387.

Ma JF, Miyake Y \& Takahashi E (2001) Silicon as a beneficial element for crop plants. In: Datnoff LE, Snyder GH \& Korndörfer GH (Eds.) Silicon in agriculture: Studies in plant science. Amsterdam, Elsevier. p.17-39.

Mali M \& Aery NC (2009) Effect of sillicon on growth, biochemical constituents, and mineral nutrition of cowpea. Communications in Soil Science and Plant Analysis, 40:1041-1052.

Medeiros LB, Vieira AO \& Aquino BF (2009) Influência da escória siderúrgica sobre trocas gasosas e produção de biomassa da canade-açúcar. Engenharia Ambiental, 6:121-129.

Melo SP, Korndörfer GH, Korndörfer CM, Lana RMQ \& Santana DG (2003) Silicon accumulation and water deficit tolerance in Brachiaria grasses. Scientia Agrícola, 60:755-759.

Nojosa GBA, Resende MLV \& Resende AV (2006) Uso de fosfitos e silicatos na indução de resistência. In: Cavalcanti LS, DiPiero RM, Pascholati SF, Resende MLV \& Romeiro RS (Eds.) Indução de resistência em plantas a patógenos e insetos. Piracicaba, FEALQ. 263p.

Novais RF, Neves JCL \& Barros NF (1991) Ensaio em ambiente controlado. In: Oliveira AJ, Garrido WE, Araujo JD \& Lourenço S (Eds.) Métodos de pesquisa em fertilidade do solo. Brasília, Embrapa-SEA. p.189-253. (Documentos, 3).

Nwugo CC \& Huerta AJ (2008) Effects of silicon nutrition on cadmium uptake, growth and photosynthesis of rice plants exposed to low-level cadmium. Plant and Soil, 311:73-86.

Orioli Júnior V, Arf O, Costa RS \& Buzetti S (2008) Modos de aplicação e doses de silício em dois cultivares de trigo cultivados em semeadura direta. Scientia Agraria, 9:377-383.

Owino-Gerroh C \& Gascho GJ (2004) Effect of silicon on low pH soil phosphorus sorption and on uptake and growth of maize. Communications in Soil Science and Plant Analysis, 35:23692378 .

Prado RM \& Fernandes FM (2000) Eficiência da escória de siderurgia em Areia Quartzosa na nutrição e na produção de matéria seca de cana-de-açúcar cultivada em vaso. STAB Açúcar, Álcool e Subprodutos, 18:36-39.

Prado RM \& Korndörfer GH (2003) Efeitos da escória de siderurgia sobre a cultura do milho (Zea mays 1.) cultivado em um Latossolo Vermelho Amarelo distrófico. Científica, 31:09-17.

Richmond RE \& Sussman M (2003) Got silicon? The non-essential beneficial plant nutrient. Current Opinion in Plant Biology, $6: 268-272$.

Savant NK, Korndörfer GH, Snyder GH \& Datnoff LE (1999) Silicon nutrition and sugarcane production: A review. Journal of Plant Nutrition, 22:1853-1903. 